\title{
Early glaciation already during the Early Miocene in the Amundsen Sea, Southern Pacific: Indications from the distribution of sedimentary sequences
}

\author{
Gabriele Uenzelmann-Neben *, Karsten Gohl \\ Alfred-Wegener-Institut Helmholtz-Zentrum für Polar- und Meeresforschung, Am Alten Hafen 26, 27568 Bremerhaven, Germany
}

\section{A R T I C L E I N F O}

\section{Article history:}

Received 14 October 2013

Received in revised form 12 June 2014

Accepted 24 June 2014

Available online 1 July 2014

Keywords:

West Antarctic Ice Sheet

sedimentary sequences

sediment drifts

bottom water circulation

variations in material input

glacial development

\begin{abstract}
A B S T R A C T
The distribution and internal architecture of seismostratigraphic sequences observed on the Antarctic continental slope and rise are results of sediment transport and deposition by bottom currents and ice sheets. Analysis of seismic reflection data allows to reconstruct sediment input and sediment transport patterns and to infer past changes in climate and oceanography. We observe four seismostratigraphic units which show distinct differences in location and shape of their depocentres and which accumulated at variable sedimentation rates. We used an age-depth model based on DSDP Leg 35 Site 324 for the Plio/Pleistocene and a correlation with seismic reflection characteristics from the Ross and Bellingshausen Seas, which unfortunately has large uncertainties. For the period before $21 \mathrm{Ma}$, we interpret low energy input of detritus via a palaeo-delta originating in an area of the Amundsen Sea shelf, where a palaeo-ice stream trough (Pine Island Trough East, PITE) is located today, and deposition of this material on the continental rise under sea ice coverage. For the period 21-14.1 Ma we postulate glacial erosion for the hinterland of this part of West Antarctica, which resulted in a larger depocentre and an increase in mass transport deposits. Warming during the Mid Miocene Climatic Optimum resulted in a polythermal ice sheet and led to a higher sediment supply along a broad front but with a focus via two palaeo-ice stream troughs, PITE and Abbot Trough (AT). Most of the glaciogenic debris was transported onto the eastern Amundsen Sea rise where it was shaped into levee-drifts by a re-circulating bottom current. A reduced sediment accumulation in the deep-sea subsequent to the onset of climatic cooling after $14 \mathrm{Ma}$ indicates a reduced sediment supply probably in response to a colder and drier ice sheet. A dynamic ice sheet since 4 Ma delivered material offshore mainly via AT and Pine Island Trough West (PITW). Interaction of this glaciogenic detritus with a west-setting bottom current resulted in the continued formation of levee-drifts in the eastern and central Amundsen Sea.
\end{abstract}

c) 2014 Elsevier B.V. All rights reserved.

\section{Introduction}

Because of modern global warming and their possible contribution to sea level rise and flooding of low lying coastal areas (e.g. Bamber et al., 2009; Gomez et al., 2010; Hu et al., 2011) both Antarctic and Greenland ice sheets have moved into the focus of public and scientific interest. Research has concentrated on short-term dynamics of the ice sheets in order to understand their vulnerability to a changing climate by collecting multi-disciplinary data (e.g. Wellner et al., 2001; Lowe and Anderson, 2002; ÓCofaigh et al., 2005; Naish et al., 2007; Nitsche et al., 2007; Bentley et al., 2010; Gomez et al., 2010; Jakobsson et al., 2010; Bart et al., 2011; Bradley et al., 2012; Konfirst et al., 2012; Hillenbrand et al., 2013) as well as carrying out numerical simulations (e.g. Thoma et al., 2008; Pollard and DeConto, 2009; DeConto et al., 2012; Assmann et al., 2013; Jacobs et al., 2013).

\footnotetext{
* Corresponding author.

E-mail address: Gabriele.Uenzelmann-Neben@awi.de (G. Uenzelmann-Neben).
}

Little has been known about the long-term development especially of the West Antarctic Ice Sheet (WAIS), which as a marine based ice sheet generally reacts more sensitively to both atmospheric and oceanic warming than the largely terrestrial East Antarctic Ice Sheet (EAIS). Information on the early phase of WAIS formation and the Cainozoic glacial history in the greater Amundsen Sea is scarce. Drilling in Wilkes Land, an area influenced by the EAIS, has shown that mid Eocene cooling there was initiated by early flow of the cold Antarctic Counter Current across the Tasmanian Gateway (Expedition 318 Scientists, 2011; Pross et al., 2012; Bijl et al., 2013). This cold Antarctic Counter Current has also bathed the Amundsen Sea implying a cold climate for that area during the Paleogene. Uenzelmann-Neben and Gohl (2012) presented indications for a pre-Miocene sea-ice cover in the Amundsen Sea based on the study of sedimentary features imaged by seismic reflection data. We here add to the discussion of the transition from pre-glacial to glacial deposition in the Cainozoic by analysing depositional patterns and the distribution of the sedimentary sequences.

Antarctic Bottom Water (AABW) originating in the Ross Sea (Gordon et al., 2009; Orsi and Wiederwohl, 2009) flows through the Amundsen 
Sea within the cyclonic Antarctic Circumpolar Current (ACC) (Orsi et al., 1999). The shelf of the Amundsen Sea is influenced by CDW reaching the fringes of the WAIS via bathymetric troughs (Jacobs et al., 1996; Thoma et al., 2008; Jacobs et al., 2011; Arneborg et al., 2012). A southwest setting flow of bottom water has been observed close to the continental slope of the Bellingshausen Sea (see Hillenbrand et al., 2008, for a detailed presentation).

Our analysis of the depositional pattern and distribution of sedimentary strata in the Amundsen Sea rise allows the reconstruction of material input from the West Antarctic continent and sediment transport processes. These in turn are strongly influenced by, and hence help us to decipher, modifications in climatic and oceanographic conditions in the Amundsen Sea, which is affected by the outflow of the Ross gyre (Orsi, 2010) and WAIS drainage.

\section{Palaeoenvironmental setting}

The Amundsen Sea along the southern Pacific margin of West Antarctica (Fig. 1) originates from rift and breakup processes and the formation of oceanic crust between Campbell Plateau/Chatham Rise and the Marie Byrd Land/Thurston Island Block at 90-80 Ma (Eagles et al., 2004; Gohl et al., 2007; and references therein). Intraplate volcanism at 65-56 Ma led to the formation of the Marie Byrd Seamounts (Kipf et al., 2013). The crystalline basement is covered by up to $4 \mathrm{~km}$ of sedimentary strata, which have been extensively reworked by oceanic currents in the deep sea (Yamaguchi et al., 1988; Nitsche et al., 2000; Uenzelmann-Neben and Gohl, 2012) and by advance-retreat cycles of the ice sheet on the shelf (Lowe and Anderson, 2002; Dowdeswell et al., 2006; Nitsche et al., 2007; Uenzelmann-Neben et al., 2007;
Graham et al., 2009; Weigelt et al., 2009; Weigelt et al., 2012; Gohl et al., 2013; Hochmuth and Gohl, 2013).

The existence and size of an early Cainozoic ice sheet in West Antarctica is still under debate as no clear evidence has been found, yet. A proto-Ross gyre (Huber et al., 2004) may have led to a cooling of surface water (Anderson, 1999). Indirect evidence points towards a significant sea ice cover in the Ross Sea in the Oligocene (Uenzelmann-Neben and Gohl, 2012). Both the opening of the Drake Passage commencing in middle Eocene times and the Tasmanian Gateway (36-30 Ma) predate the largest $\delta^{18} \mathrm{O}$ increase (Oi1) of the past $50 \mathrm{Ma}$, which is interpreted to represent the onset of major glaciation in Antarctica (Huber et al., 2004; Miller et al., 2008; Francis et al., 2009).

It has been suggested that mountain glaciers and ice caps existed in West Antarctica during the Oligocene, with ice streams spreading into the western Ross Sea (Anderson, 1999) and advancing to sea level in other regions (Miller et al., 2008). Ivany et al. (2006) reported a regionally extensive ice sheet for the Antarctic Peninsula during the Oligocene, while Cooper et al. (2009) observed aggradation on the West Antarctic shelf, high-relief canyons on the continental slope and channel-levees on the rise during that time.

The Mi1 excursion (Oligocene-Miocene boundary) represents a short-lived ( $200 \mathrm{ka}$ ) increase in ice volume from $40 \%$ to $125 \%$ of the present volume (Wilson et al., 2009). Haywood et al. (2009) report further growth of the WAIS at 14 Ma with Bart (2003) observing at least two WAIS expansions to the Ross Sea shelf edge. The West Antarctic shelf during the Miocene is characterised by uniform progradation with erosion of topset strata (Cooper et al., 2009). The slope and rise showed fan growth and the construction of large sediment drift bodies and channel-levees (Cooper et al., 2009; Uenzelmann-Neben and Gohl,

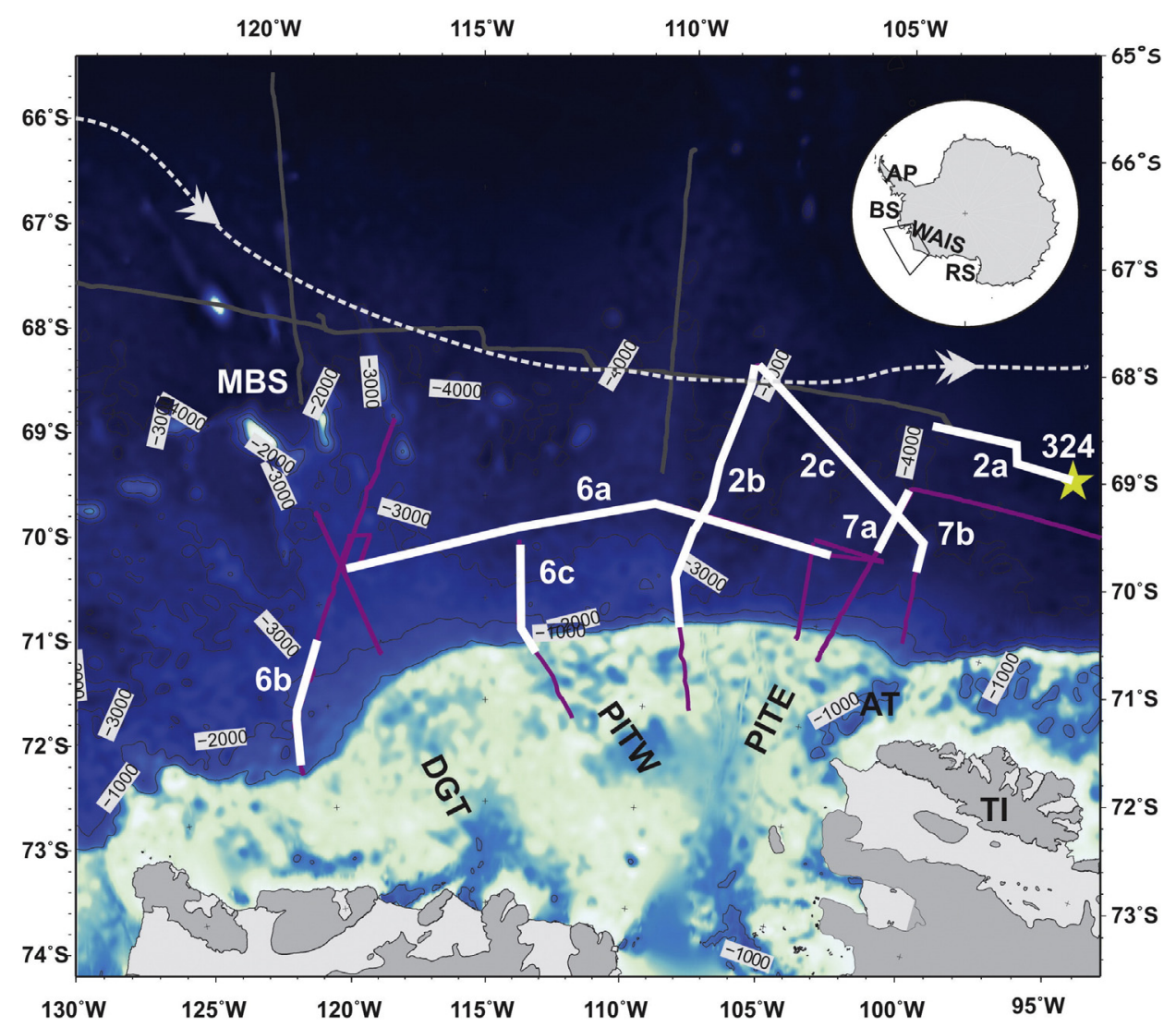

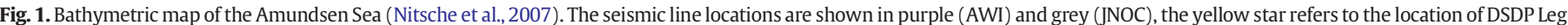

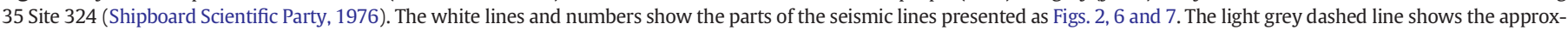

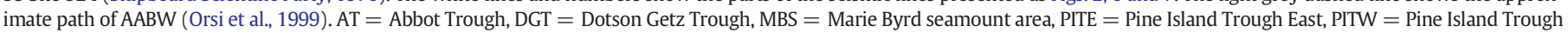
West, $\mathrm{TI}=$ Thurston Island. Insert map shows the area presented. AP $=$ Antarctic Peninsula, BS $=$ Bellingshausen Sea, RS $=$ Ross Sea, WAIS $=$ West Antarctic Ice Sheet. 
2012). Starting in late Miocene glacial-interglacial volumes were deposited further landward.

A regional unconformity characterises the Miocene-Pliocene boundary at the West Antarctic continental margin (Cooper et al., 2009). A strong increase in sea surface temperatures occurred during several warm intervals in the Pliocene (Escutia et al., 2009; Haywood et al., 2009). A change from polythermal to polar cold, dry-based ice sheets at ca. 3 Ma has been suggested by Rebesco and Camerlenghi (2008). Rapid oscillations and volume changes of the WAIS in the Ross Sea region during the middle Pliocene were reconstructed from sedimentary sequences deposited in open water and at the base of grounded ice, respectively (Naish et al., 2009a; Naish et al., 2009b). Numerical simulations of WAIS variations for the past 5 million years supported by drilling results from the Ross Sea indicate phases with intermediate to full glacial extent and brief intervals of ice-sheet collapse leaving only small isolated ice caps (Pollard and DeConto, 2009).

Most information on WAIS dynamics is available for the period since the last glacial maximum and is based on geomorphological, sedimentological and chronological data sets collected predominantly from the shelves in the Amundsen and Ross seas (e.g. Domack et al., 1999; Lowe and Anderson, 2002; Smellie et al., 2009; Anderson et al., 2011; Jakobsson et al., 2012; Kirshner et al., 2012; Livingstone et al., 2012; Klages et al., 2013). On the outer continental shelf of the eastern Amundsen Sea Embayment the glacial trough eroded by the Pine Island-Thwaites palaeo-ice stream had two outlets: The eastern Pine Island Trough (PITE) with a mouth at $\sim 106^{\circ} \mathrm{W}$ (Graham et al., 2010) and the western Pine Island Trough (PITW) with a mouth at $\sim 114^{\circ} \mathrm{W}$ (Evans et al., 2006). During the last few glacial periods palaeo-ice stream flow may either have switched between these two outlets or ice streamed in the whole area between PITW and PITE (Lowe and Anderson, 2002; Evans et al., 2006; Graham et al., 2010; Jakobsson et al., 2012).

A few studies investigated the relationship between ice sheet dynamics and changes in oceanographic conditions for the Amundsen and Bellingshausen Seas. On the basis of seismic reflection profiles from the western Antarctic Peninsula margin that were correlated with drill cores, Rebesco et al. (2002) and Uenzelmann-Neben (2006) identified a close interaction of contouritic and turbiditic sediment transport with indications for a major advance of the local ice sheet shortly after $15 \mathrm{Ma}$. There is widespread evidence for bottom current activity since $~ 9.6 \mathrm{Ma}$ in this area and in the Bellingshausen Sea further to the west (e.g. Nitsche et al., 2000; Rebesco et al., 2002; HernandezMolina et al., 2004; Hillenbrand and Ehrmann, 2005; Scheuer et al., 2006b; Uenzelmann-Neben, 2006). Uenzelmann-Neben and Gohl (2012) inferred bottom current activity as early as the Paleogene and the onset of major glaciations in West Antarctica at 14.1 Ma from seismic reflection profiles on the continental rise in the Amundsen Sea, but chronological control was poor.

The study presented here builds on the analysis of sedimentary structures by Uenzelmann-Neben and Gohl (2012). Adding new seismic profiles and analysing the distribution of the seismic units we will contribute to a better understanding of material input from the West Antarctic continent and sediment transport processes.

\section{Methods}

\subsection{Database}

This study is based on multichannel seismic reflection data gathered by the Alfred-Wegener-Institut (AWI) in 1994, 2006 and 2010 (Fig. 1). Details of field parameters and processing of the seismic data gathered in 1994 and 2006 can be found in Gohl et al. (1997), Nitsche et al. (2000) and Uenzelmann-Neben et al. (2007). During the cruise in 2010 four GI-guns $\odot$, with a volume of about $2.4 \mathrm{l}$ each, were used as a seismic source. Each of the GI-guns $(\subset$ consisted of a generator chamber ( 0.721 volume) producing the seismic signal, and an injector chamber (1.68 l volume), which was triggered with a 33 ms delay to suppress the bubble. The GI-guns $\subseteq$ were fired every $10 \mathrm{~s}$ (corresponding to a shot-spacing of approximately $25 \mathrm{~m}$ ), producing signals with frequencies of up to $300 \mathrm{~Hz}$. Data were received using a digital seismic data acquisition system (SERCEL SEALC), consisting of both onboard and in-sea equipment. The total active streamer length was $3000 \mathrm{~m}$, consisting of 240 channels.

Processing of the seismic reflection data comprised geometry definition using the ship's navigation data, and CDP-sorting with a CDP spacing of $25 \mathrm{~m}$. No deconvolution was carried out, since the short signal and absence of seafloor multiples in our data did not require this. A precise velocity analysis (every $50 \mathrm{CDP}$ ) was carried out and used for normal move-out correction. Stacking velocities are accurate within $10 \%$ and were converted to interval velocities using Dix's formula (Yilmaz, 2001). Residual static corrections and coherency filters were applied to further improve the data quality. After stacking, an Omega-X time migration was carried out, to correctly image strongly inclined surfaces (Yilmaz, 2001). No gain was applied to the data, neither during processing nor for display. Thus, differences in reflection amplitude discussed in the following are real. Additional seismic data (Yamaguchi et al., 1988) were available via the digital database of the SCAR Antarctic Seismic Data Library System (SDLS).

DSDP Leg 35 Site 324 (Fig. 1), the only drill site in the study area, was crossed by profile TH-86002a (Yamaguchi et al., 1988) but unfortunately this site only provided information on the uppermost $200 \mathrm{~m}$ of the sedimentary column (Shipboard Scientific Party, 1976; Tucholke et al., 1976a). Core 324 retrieved sediments consisting of sand, silty clay and diatomaceous clay of Pliocene to Pleistocene age, but recovery was relatively poor (51\%) (Shipboard Scientific Party, 1976). Other direct information concerning the time frame from drill sites is either too far away or from different environments or both (DSDP Leg 35 Site 323-380 nm, deep sea (Tucholke et al., 1976b); ODP Leg 178 Sites 1095 and 1096-540 nm, continental rise (Iwai et al., 2002); DSDP Leg 28 Site 271-1500 nm, Ross Sea shelf (Shipboard Scientific Party, 1975b); DSDP Leg 28 Site 274-2000 nm, continental rise (Shipboard Scientific Party, 1975a)).

\subsection{Seismostratigraphic model}

Uenzelmann-Neben and Gohl (2012) put forward a seismostratigraphic model for the wider Amundsen Sea. They used the age-depth model provided by DSDP Leg 35 Site 324 (Shipboard Scientific Party, 1976) for the upper $200 \mathrm{~m}$ of the sedimentary column comprising Pliocene/Pleistocene units and correlated this with observations on general changes in reflections characteristics. Variations in reflection characteristics for the deeper lying sequences were interpreted to represent modifications in the depositional regime and compared to observations from the Bellingshausen Sea (; Tucholke and Houtz, 1976; Tucholke et al., 1976b; Rebesco et al., 1996; Nitsche et al., 1997; Nitsche et al., 2000; Rebesco et al., 2002; Scheuer et al., 2006a; Scheuer et al., 2006b), which were tied to DSDP Leg 35 and ODP Leg 178 results, and the Ross Sea (De Santis et al., 1995; De Santis et al., 1999; Böhm et al., 2009), there correlated with results from DSDP Leg 28 , to derive an age model. We make use of this stratigraphic model being aware of its poor chronological control but modify the names of the sedimentary units to distinguish them from the Ross Sea and Amundsen Sea shelf by adding the acronym ASR (Amundsen Sea rise).

Uenzelmann-Neben and Gohl (2012) identified four sedimentary units on top of basement (Fig. 2, Table 1). The oldest unit ASR-I is characterised by weak internal reflections and is partly transparent. This unit fills the basement topography (Fig. 2a) and is assumed to represent the period from $\sim 60$ to $21 \mathrm{Ma}$. Unit ASR-I shows elongate sedimentary drifts in the Marie Byrd Seamount area as a result of an eastward flow of bottom water. Sedimentary unit ASR-II was deposited between $21 \mathrm{Ma}$ and 14.1 Ma and shows variable, continuous internal reflections of moderate to high amplitude (Fig. 2a, b and e, Table 1). 

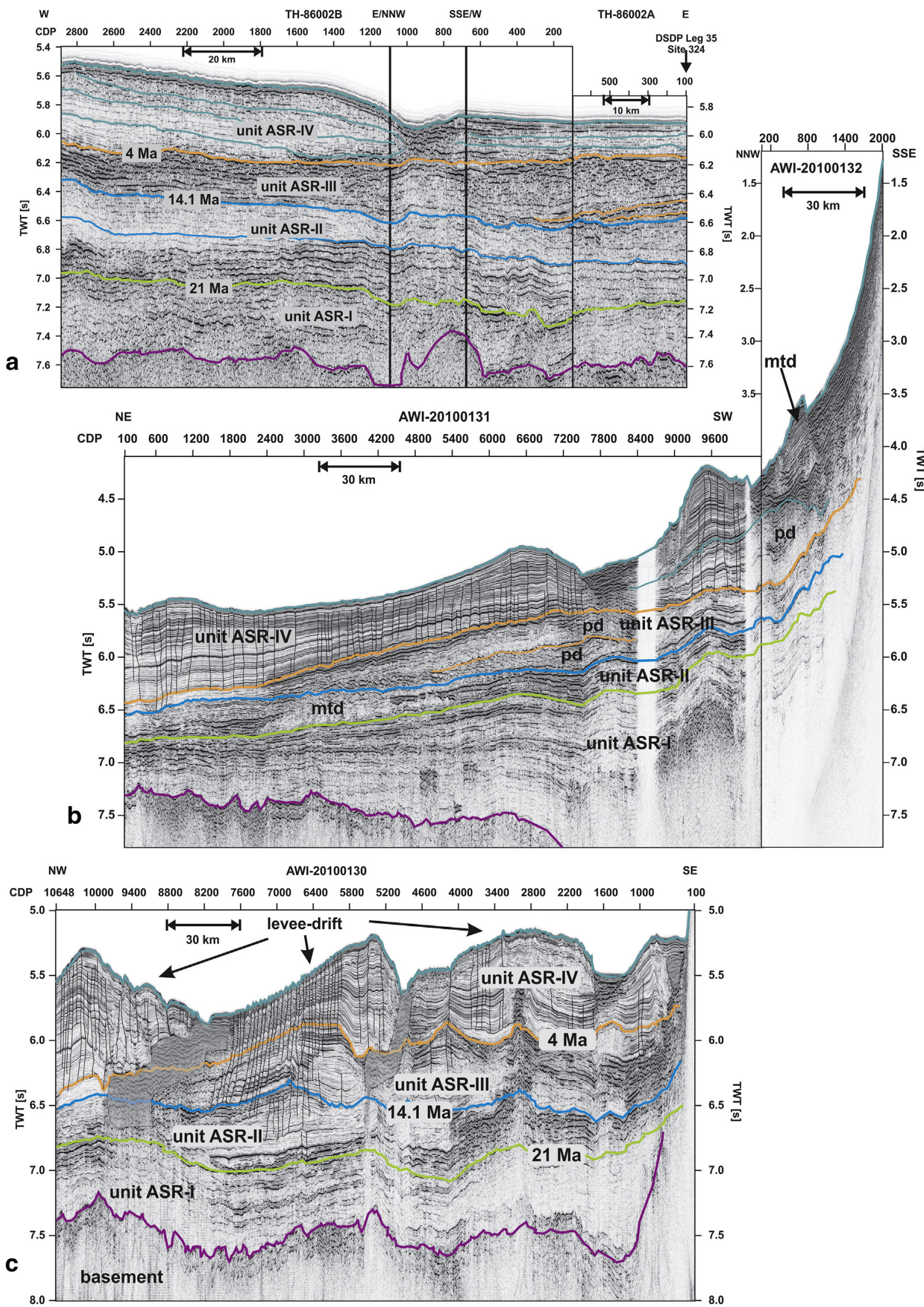

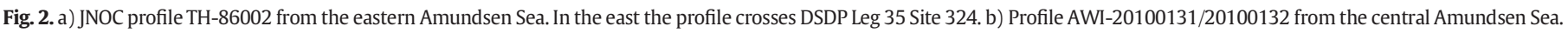

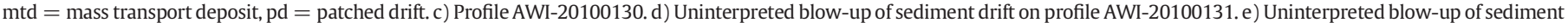

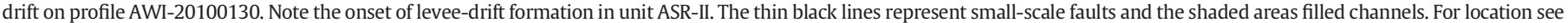
Fig. 1. 
NE

AWI-20100131

sw

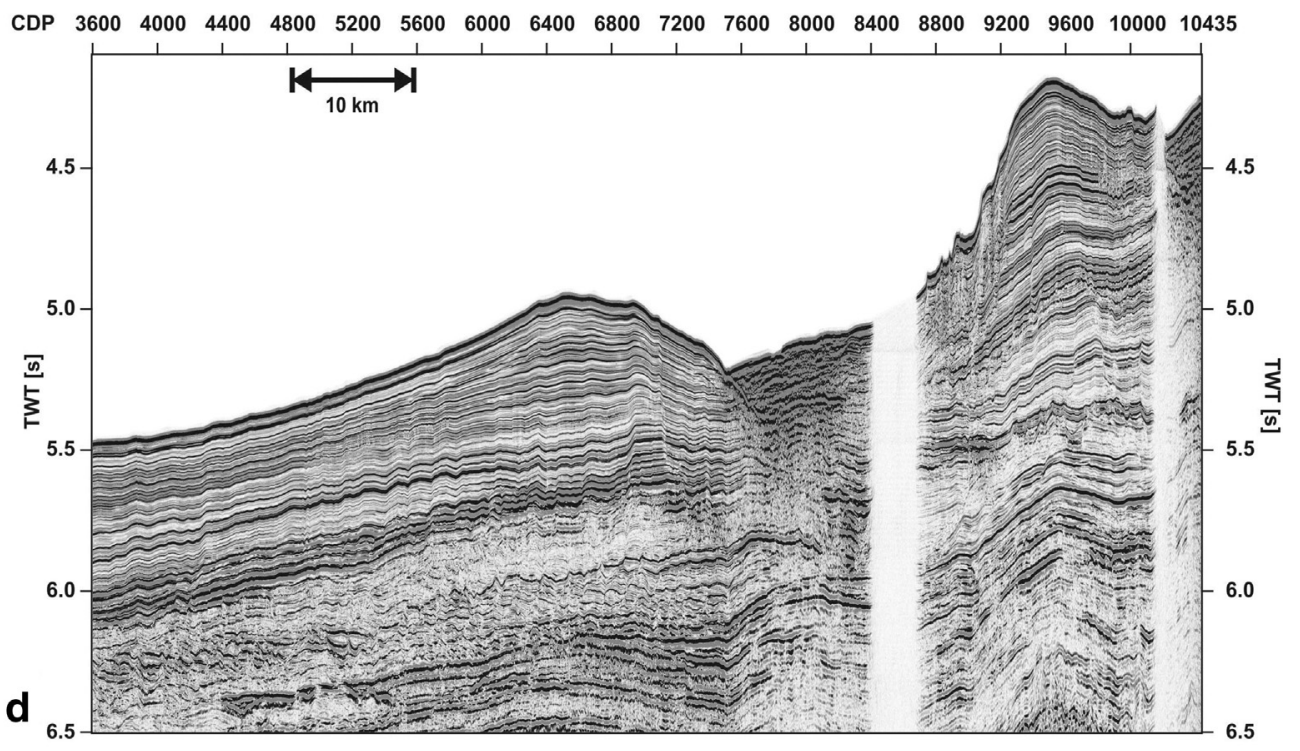

\section{NW}

AWI-20100130

SE

CDP 8800860084008200800078007600740072007000680066006400620060005800560054005200500048004600

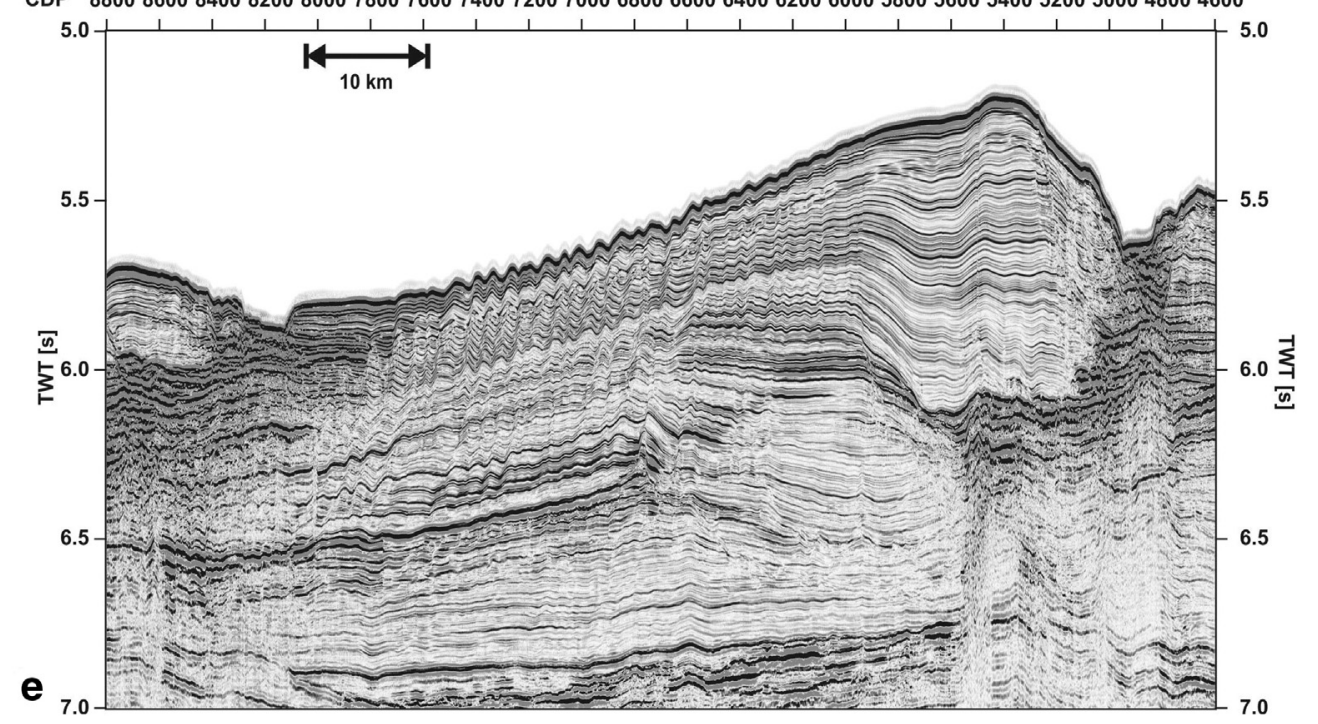

Fig. 2 (continued)

Elongate drifts can be observed within this unit in the Marie Byrd Seamount area while levee-drifts characterise the unit in the eastern Amundsen Sea (Fig. 2c and e). Both drift types are interpreted to relate to intensified bottom water activity.

In sedimentary unit ASR-III (14.1-4 Ma) an increase in internal reflections and mass transport deposits additionally to elongate and levee-drifts were observed (Fig. 2, Table 1). This was interpreted to represent a further intensification of bottom water activity and an advancing ice sheet. The youngest sedimentary unit ASR-IV (4-0 Ma) shows moderate, well layered reflections separated by several unconformities (Fig. 2, Table 1). Levee-drifts and mass transport deposits observed in this unit were interpreted as results of a southward shift of the bottom water and a change in basal ice-sheet conditions to polythermal.

The basal reflectors of units ASR-I to ASR-IV, and the seafloor reflection of all existing seismic profiles of the Amundsen Sea slope and rise were tracked, thicknesses of the different units computed, and maps of reflector depths and unit thicknesses compiled with the aim to better define and describe the sedimentary environments. We converted the reflector depths and unit thicknesses into depth using interval velocities derived from stacking velocities using Dix's Formula.

Palaeo-seafloor highs and depocentres will be presented and discussed. Although these terms usually are used as the highest locations and thickest part, respectively, we specifically defined them as the root mean square (rms) value of the reflector depth and unit thickness, respectively, in order to be explicit and avoid equivocality. Within the depocentres we observed additional foci of deposition, which we pointed out. Shape and location of a depocentre relative to the continental slope and older depocentres reveal the loci of major sediment accumulation and allow conclusions about transport pathways and processes. A depocentre oriented parallel to the slope is interpreted to document dominance of along-slope sediment transport, whereas a depocentre perpendicular to the slope is interpreted to indicate dominance of down-slope sediment transport. We also computed accumulation rates for the depocentres (Table 2). These observations are combined with the occurrence of sedimentary features in the study area, such as sediment drifts and 
Table 1

Seismostratigraphic model of Uenzelmann-Neben and Gohl (2012).

\begin{tabular}{|c|c|c|c|c|c|c|}
\hline $\begin{array}{l}\text { Sedimentary } \\
\text { unit }\end{array}$ & Proposed age & $\begin{array}{l}\text { Thickness } \\
\text { ( } \min , \text { max) } \\
\text { in ms TWT } \\
\text { (in } \mathrm{m} \text { ) }\end{array}$ & Reflection characteristics & Sedimentary features & Main area of occurrence & $\begin{array}{l}\text { Oceanographic/climatological } \\
\text { interpretation }\end{array}$ \\
\hline ASR-I & 60 (?)-21 Ma & $\begin{array}{l}100-1600 \\
(250-4000)\end{array}$ & $\begin{array}{l}\text { Weak internal reflections, partly } \\
\text { transparent, infill of basement } \\
\text { topography }\end{array}$ & Elongate sediment drifts & Marie Byrd Seamounts & $\begin{array}{l}\text { Eastward flow of bottom water } \\
\text { (proto-AABW?) }\end{array}$ \\
\hline ASR-II & $21-14.1$ & $\begin{array}{l}100-600 \\
(175-1050)\end{array}$ & $\begin{array}{l}\text { Variable, continuous internal } \\
\text { reflections of moderate to high } \\
\text { amplitude in either the lower or } \\
\text { upper part, downlap onto base }\end{array}$ & Elongate drifts levee-drifts & $\begin{array}{l}\text { Marie Byrd Seamounts } \\
\text { eastern Amundsen Sea }\end{array}$ & $\begin{array}{l}\text { Intensified bottom water activity } \\
\text { cyclonic eddies shed from bottom } \\
\text { water? }\end{array}$ \\
\hline ASR-III & $14.1-4$ & $\begin{array}{l}100-800 \\
(150-1200)\end{array}$ & $\begin{array}{l}\text { Increase in number of internal } \\
\text { reflections }\end{array}$ & $\begin{array}{l}\text { Elongate drifts levee-drifts } \\
\text { mass transport deposits }\end{array}$ & $\begin{array}{l}\text { Marie Byrd Seamounts } \\
\text { eastern Amundsen Sea } \\
\text { central/eastern Amundsen } \\
\text { Sea }\end{array}$ & $\begin{array}{l}\text { Intensified bottom water activity } \\
\text { cyclonic eddies shed from bottom } \\
\text { water advancing ice sheet }\end{array}$ \\
\hline ASR-IV & $4-0$ & $\begin{array}{l}200-1300 \\
(200-1300)\end{array}$ & $\begin{array}{l}\text { Moderate, well-layered reflections } \\
\text { separated by several unconformities }\end{array}$ & $\begin{array}{l}\text { Levee-drifts mass transport } \\
\text { deposits }\end{array}$ & $\begin{array}{l}\text { Eastern Amundsen Sea near } \\
\text { continental rise }\end{array}$ & $\begin{array}{l}\text { Bottom water activity has shifted } \\
\text { southwards, less intense change in } \\
\text { ice regime from wet- to dry-based }\end{array}$ \\
\hline
\end{tabular}

mass transport deposits (mass transport deposits), that have been previously reported.

We are aware of the fact that the number of seismic lines is small and they are far apart. This results in a certain ambiguity of our findings. Still, we consider it important to report and discuss our observations to provoke further research in this area. We thus limit the discussion to changes and trends.

\section{Results}

The top of the basement shows a high in the area of the Marie Byrd Seamounts (MBS) (Fig. 3a, shaded area). This high extends slightly NEwards. The deepest basement is observed between PITW and AT. Unit ASR-I shows a broad depocentre (shaded area in Fig. 4a) parallel to the continental slope, which does not extend far into the ocean. The thickest parts of the depocentre ( $>2500 \mathrm{~m}$, bold outline) can be observed a) continent-wards of the MBS in front of the Dotson-Getz Trough (DGT), b) between Pine Island Trough West (PITW) and PITE, and c) in front of Abbott Trough (AT) (Fig. 4a, black outlined areas).

The base of unit ASR-II also shows a high in the MBS area (shaded in Fig. 3b). This high is smaller than the one observed for the basement. We observe an extension towards the SE (to the slope offshore from PITW) rather than towards the NE. The deepest part of the horizon is located in the NE of the area of investigation with two smaller troughs seaward of PITW. Unit ASR-II again shows a broad depocentre (shaded in Fig. 4b) parallel to the continental slope, which extends further into the ocean than unit ASR-I's depocentre (Fig. 4a and b). The thickest parts of the depocentre as outlined by the black lines in Fig. $4 \mathrm{~b}(>750 \mathrm{~m}$ ) can be observed a) in the NE offshore from PITE, b) in three locations in front of PITW and further to the W, and c) in front of AT. Two of the three thick depocentres have been deposited in up to $250 \mathrm{~m}$ deep troughs (Fig. 3b) but the westernmost depocentre directly indicates an increased sediment input. The foci of the depocentres have shifted relative to those of unit ASR-I except the one in front of AT.

The MBS area appears still elevated at the base of unit ASR-III but is less pronounced (Fig. 3c). The shallowest part is found closer towards the continental slope. Similar to the base of ASR-II that of ASR-III lies relatively deep in the NE. For unit ASR-III we observe no longer a single, but two depocentres that coincide with locations where ASR-II had been thickest: a) in front and slightly west of PITW, and b) in front and slightly west of AT (Fig. 4c). Depocentre a) is still parallel to the shelf break and the continental slope, whereas depocentre $b$ ) is oriented perpendicular to shelf break and continental slope.

For the base of unit ASR-IV we observe a broad high, which extends eastwards from the MBS and is oriented parallel to the shelf break (Fig. 3d). The NE is characterised by a deep lying base of ASR-IV, which is less pronounced and deepens towards the deep sea. Unit ASR-IV shows depocentres only in the eastern part of the study area, where they cover about the same areas as the depocentres in unit ASR-III (Fig. 4c and d, Table 2). Three depocentres are located between AT and PITW and are oriented perpendicular to the continental slope. The thickest parts (>800 ms TWT) are found on the continental slope.

\section{Discussion}

The sedimentary units show distinct depocentres and some of those have shifted through time. The distance between the seismic lines covering the study area is large in parts (Fig. 1) and thus the

Table 2

Characteristics for the sedimentary units and the associated depocentres.

\begin{tabular}{|c|c|c|c|c|c|c|c|}
\hline \multirow[t]{2}{*}{ Unit, age } & \multirow[t]{2}{*}{ Base reflector } & \multicolumn{6}{|l|}{ Depocentre } \\
\hline & & $\begin{array}{l}\text { Form } \\
\text { (rms value of unit thickness) }\end{array}$ & $\begin{array}{l}\text { A } \\
\left(\mathrm{km}^{2}\right) \\
\text { with } \mathrm{v}_{\mathrm{P}} \\
(\mathrm{m} / \mathrm{s})\end{array}$ & $\begin{array}{l}\text { Thickness } \\
(\mathrm{m})\end{array}$ & $\begin{array}{l}\text { Volume } \\
\left(10^{13} \mathrm{~m}^{3}\right)\end{array}$ & $\begin{array}{l}\text { Sedimentation } \\
\text { rate } \\
(\mathrm{m} / \mathrm{my})\end{array}$ & $\begin{array}{l}\text { Accumulation } \\
\text { rate } \\
\left(\mathrm{m}^{3} / \mathrm{my}\right)\end{array}$ \\
\hline ASR-I, (60?)-21 Ma & High in MBS area, low in the east & $\begin{array}{l}\text { Broad front of shelf, does not extend } \\
\text { far into ocean; thickest part between } \\
\text { AT and PITW }\end{array}$ & $29,511(5000)$ & 1778 & 5.247 & 45 & $1.3 * 10^{12}$ \\
\hline ASR-II 21-14.1 Ma & $\begin{array}{l}\text { MBS high smaller, closer to } \\
\text { continental slope, low in the NE }\end{array}$ & $\begin{array}{l}\text { Broad, extending farther into ocean, } \\
\text { thickest part in NE and in front of AT } \\
\text { and PITE }\end{array}$ & $53,255(3500)$ & 599 & 3.189 & 86.7 & $4.6 * 10^{12}$ \\
\hline ASR-III 14.1-4 Ma & MBS high less pronounced & $\begin{array}{l}2 \text { main depocentres: a) in front and } \\
\text { west of AT, } \perp \text { shelf break, b) in front } \\
\text { and west of PITW, } \| \text { shelf break }\end{array}$ & $32,918(3000)$ & 594 & 1.955 & 58.96 & $1.9 * 10^{12}$ \\
\hline ASR-IV 4-0 Ma & $\begin{array}{l}\text { MBS high \| to shelf break, still } \\
\text { highest in the } W\end{array}$ & Between AT and PITW, $\perp$ shelf break & $30,412(2000)$ & 578 & 1.758 & 144.5 & $4.4 * 10^{12}$ \\
\hline
\end{tabular}



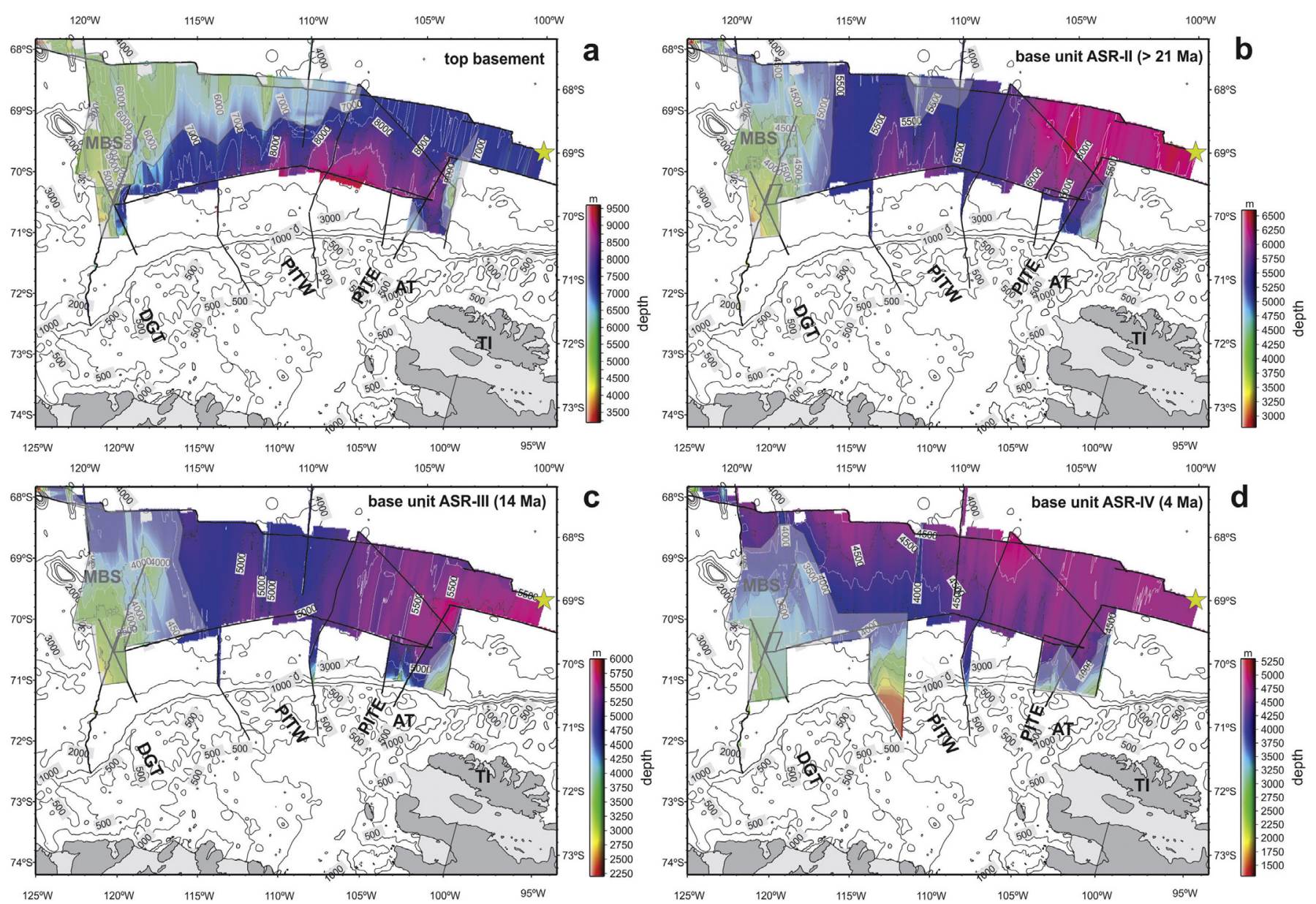

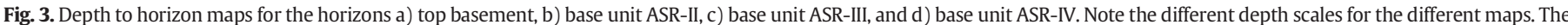

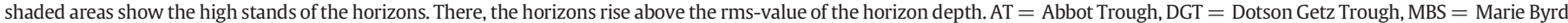
seamount area, PITE = Pine Island Bay Trough East, PITW = Pine Island Trough West, TI = Thurston Island.

interpolation of the picked horizons and sedimentary units into the uncovered parts is affected by uncertainties. Nevertheless, the general trend observed in both horizon depth and unit thickness is probably correct and will be interpreted with respect to sediment material input (dimension and favoured path) and transport process (downslope versus along-slope). This discussion will then lead to inferences on modifications in climatic and oceanographic conditions. The bottom current paths are inferred from the occurrence and distribution of sedimentary features, e.g. sediment drifts and mass transport deposits (for details see (Uenzelmann-Neben and Gohl, 2012)).

Sedimentary unit ASR-I appears to be dominated by the basement high in the area of the MBS (Figs. 3a and 4a). This area obviously had been elevated since the MBS magmatism, which is at least 56 Ma old (Kipf et al., 2013). This high appears to have prevented material transport from the slope to the northwest, which is documented by the depocentre observed between the MBS and the continental shelf (Fig. 4a). The thickest part of the unit ASR-I depocentre is found in the eastern part of the study area, where sediments filled a depression in the basement (Figs. 3a and 4 a). This depocentre lies between AT and PITW.

The sedimentation rate with an rms value of $45 \mathrm{~m} / \mathrm{my}$ lies well within the range for a deep sea environment (Table 2). We observe sediment input along the whole continental margin with a focus between AT and PITW (Fig. 5a). Unit ASR-I appears to level out the basement topography. Uenzelmann-Neben and Gohl (2012) reported sediment drift formation within sedimentary unit ASR-I north of and within the MBS area. They concluded that a bottom current shaping those drifts was deflected by the MBS around them, but did not influence the upper continental rise. The sedimentation east of the MBS therefore was not influenced by the bottom current and thus the basement topography there could be levelled out by sediment infill (Fig. 5a).

As the area of the MBS was elevated ( $2000 \mathrm{~m}$ at $56 \mathrm{Ma}$, (Kipf et al., 2013)), the water mass shaping the sediment into sediment drifts (see Fig. 2 of Uenzelmann-Neben and Gohl, 2012) could not have flown as deep as AABW does today (4000 $\mathrm{m}$ and deeper, Van Aken, 2007). This indicates a lower density for the water mass. The formation of a bottom/deep water with a lower density may not require full glacial conditions but only a significant sea ice cover in winter as suggested by Uenzelmann-Neben and Gohl (2012). We rule out halothermal bottom/deep water formation, since this appears to be restricted to very warm and confined basins (Van Aken, 2007). Furthermore, a cold westward flowing Antarctic Counter Current has been reported to have initiated mid Eocene cooling in Wilkes Land and downward convection after the opening of the Tasmanian Gateway 49-50 Ma (Expedition 318 Scientists, 2011; Bijl et al., 2013) thus supporting this hypothesis.

In their reconstruction of the Antarctic topography at $34 \mathrm{Ma}$, Wilson et al. (2012) infer an increased ice volume for West Antarctica at the Eocene/Oligocene boundary. They suggest a terrestrial ice sheet for the Early Oligocene, which would have been less affected by sea level changes and ocean temperature variations. The detritus eroded by this early ice sheet was deposited mainly in the West Antarctic Rift and little material was transported towards the Amundsen Sea (Wilson et al., 2012). Combining this information with the discussion presented by Uenzelmann-Neben and Gohl (2012), who suggest a cool climate with a significant sea-ice cover to allow bottom/deep water formation 

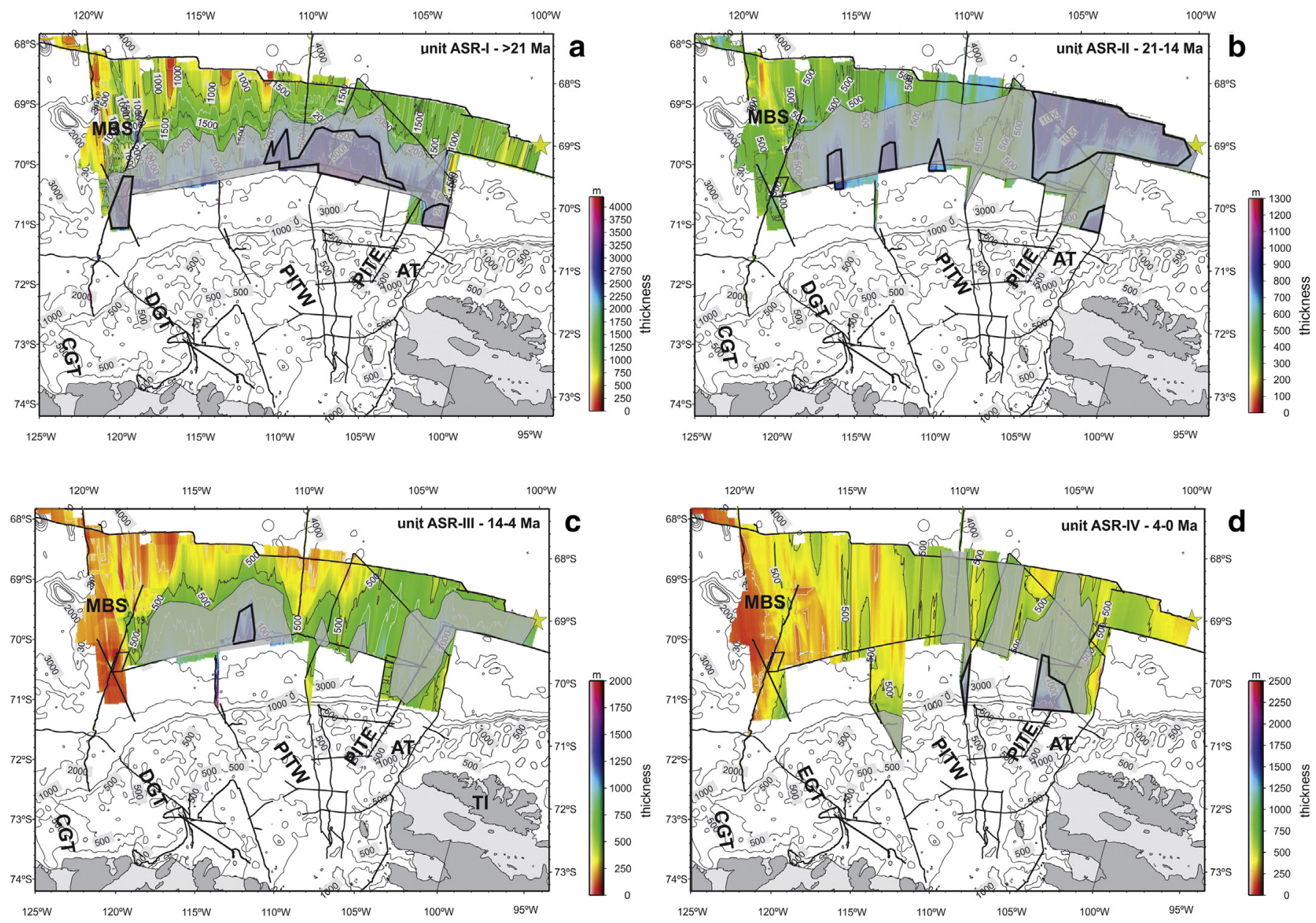

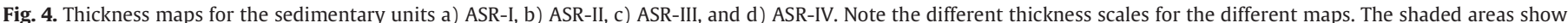

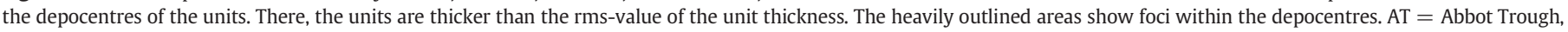
DGT $=$ Dotson Getz Trough, MBS = Marie Byrd seamount area, PITE = Pine Island Trough East, PITW = Pine Island Trough West, TI $=$ Thurston Island.

already in Eocene/Oligocene times, and the lack of channels and mass transport deposits observed in our seismic profiles for unit ASR-I (Figs. 2c and 6), we argue for a continuous, low-energy sediment input from the continent with depositional foci offshore from the DGT, the AT and the outer shelf between PITE and PITW (Fig. 5a). Graham et al. (2010) discuss a broad ice stream outflow spanning from PITE to PITW for the late Quaternary covering an accumulation area of $\sim 500,000 \mathrm{~km}^{2}$ at the last glacial maximum (LGM). Taking this into account we interpret the foci of the ASR-1 depocentres as palaeo-deltas and suggest that at least on the outer shelf the modern palaeo-ice stream troughs reflect the locations of river beds, which have been located there before $21 \mathrm{Ma}$. The rivers delivered the main sediment load to the palaeo-shelf break in a low energy environment (Fig. 5a).

The MBS area influences the depth of the base of unit ASR-II, with the palaeo-seafloor high having slightly shifted towards the continental slope (Fig. 3b). We interpret this shift as the consequence of the formation of the western ASR-I depocentre. The ASR-II depocentre is still broad and parallel to the continental slope but extends much farther northwards than that of unit ASR-I (Fig. 4b). It covers roughly $53,225 \mathrm{~km}^{2}$, which is almost twice the size of unit ASR-I's depocentre (Table 2). A possible interpretation would be simply a build-out of the shelf break, which during deposition of unit ASR-I may have lain further south. Studying seismic lines on the Amundsen Sea shelf, Gohl et al. (2013) did not see any indications for progradation and a northward shift of the shelf break for the period 21-14.1 Ma, which is supported by our lines crossing the continental slope and rise (Figs. 2c, $6 \mathrm{~b}$, and c). Sedimentation rates also have nearly doubled within unit
ASR-II (Table 2). This points towards increased sediment input along this part of the Amundsen Sea embayment (Fig. 5b), which we attribute to intensified glacial erosion in the hinterland due to a growth of mountain glaciers that may have coalesced to ice caps and not just a build-out of the shelf. Consequently, we conclude glacial conditions in this part of West Antarctica already during the Early Miocene.

This hypothesis is supported by the findings of Rocchi et al. (2006), who could demonstrate that ice caps had affected the Amundsen Sea hinterland possibly as early as 29-27 Ma and certainly by ca. $15 \mathrm{Ma}$. According to our age model unit ASR-II covers the period from Mi 1a (21.2 Ma, Miller et al., 1991) to the mid-Miocene Climatic Optimum (MMCO) (17-15 Ma, Miller et al., 1987; Zachos et al., 2001). Deep-sea oxygen isotope data on benthic foraminifera show that the Antarctic ice sheet underwent periods of instability during this time (e.g. Zachos et al., 2001). The ice sheet was polythermal, which resulted in high rates of glacial erosion and production of melt water delivering large volumes of suspended material to the continental margin (Haywood et al., 2009). The uplift of coastal Marie Byrd Land since about 29-25 Ma due to a mantle plume appears to have aided increased sediment input via the formation of mountain glaciers (LeMasurier, 2008). West of the Antarctic Peninsula, down-slope sediment transport increased from 15 to 9.5 Ma (Uenzelmann-Neben, 2006). We suggest that ice in the hinterland of the Amundsen Sea Embayment was more sensitive to warming trends towards the MMCO. This may indicate not only the existence of mountain glaciers for this period but a marine-based low-altitude ice sheet as well, which is more sensitive to variations in air temperature (e.g. Pritchard et al., 2012). 

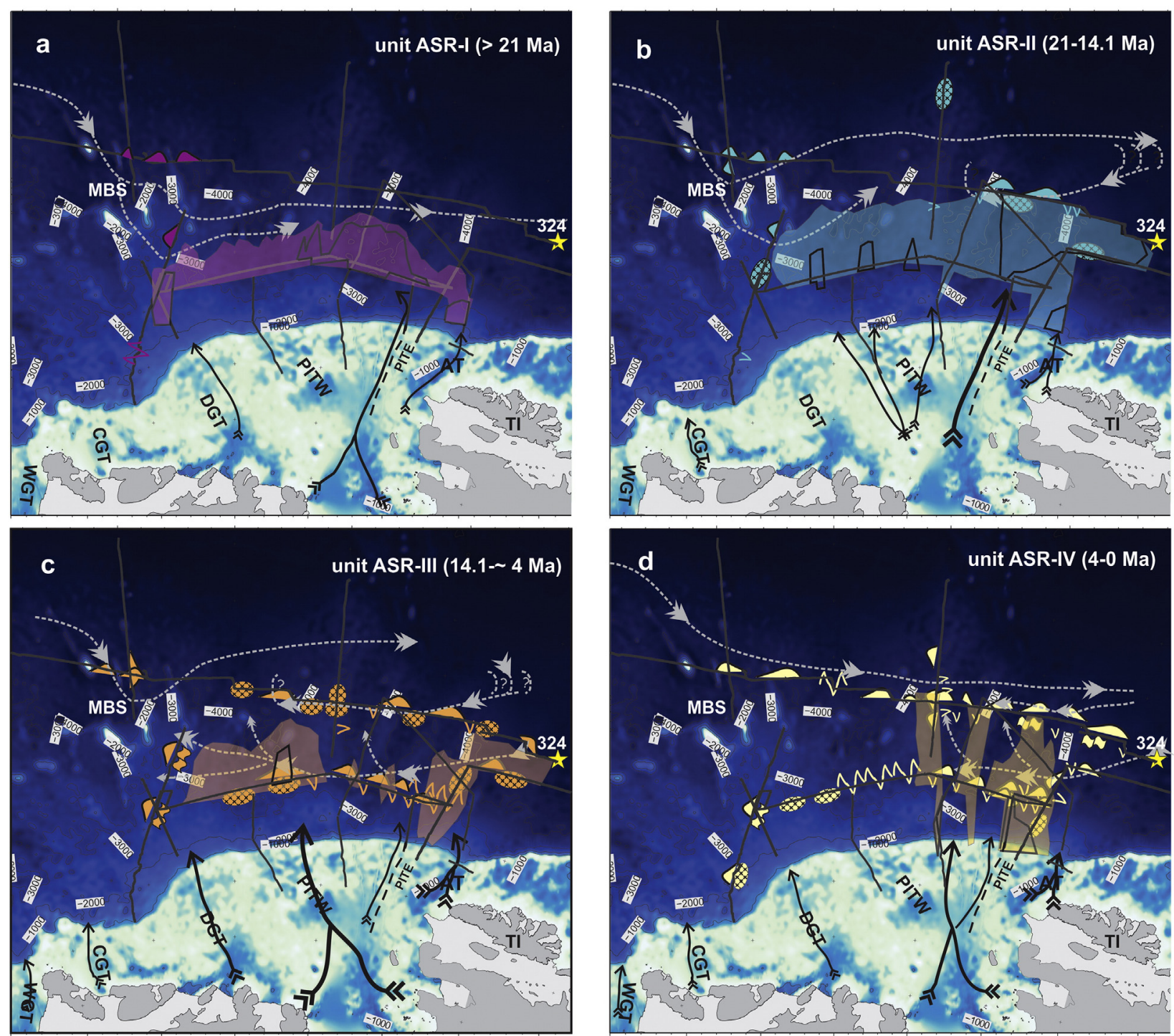

$7 \begin{gathered}\text { sediment mass } \\ \text { transport } \\ \text { path }\end{gathered} M_{\text {channel-levee }}^{\text {bottom current }} \times \infty$

deposit

sediment drift

$\checkmark$ channel

WW sediment waves

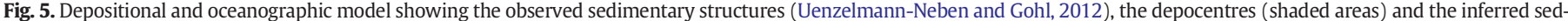

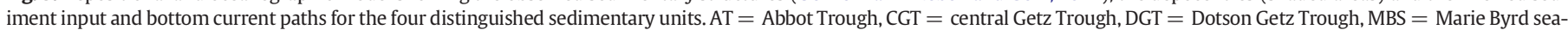
mount area, PITE $=$ Pine Island Trough East, PITW $=$ Pine Island Trough West, WGT $=$ western Getz Trough.

The thickest part of unit ASR-II's depocentre is found in the NE and has a slope parallel shape (Fig. 4b). A narrower thick part of the depocentre lies directly seaward of AT. Obviously the sedimentary material was channelized through AT and PITE in a higher energy environment (please note the increased number of channels and mtds in this unit, Figs. 2b, 6a and b, and 7b), partly deposited seaward of AT and PITE (Fig. 5b), but most of the material was transported farther seawards. There, the sediment was shaped into levee-drifts by a recirculated bottom-current (Figs. 2c and e and 5b). Three smaller foci of unit ASR-II's depocentre north of PITW are probably the result of continued input via the proposed palaeo-delta.

The MBS region still forms a palaeo-seafloor high at the base of unit ASR-III but is less elevated above the surrounding seabed (Fig. 3c). Material input from the shelf apparently was much reduced during deposition of unit ASR-III. Instead of one large depocentre, we now observe two with a size reduced to about $60 \%$ of the size of the unit ASR-II depocentre (Fig. 4c) and a sedimentation rate reduced to 70\% compared to that of unit ASR-II (Table 2). The eastern unit ASR-III depocentre lies seaward of the AT, but it is smaller than the thickest part of the unit ASRII depocentre. This depocentre is aligned perpendicular to the continental slope in its southern part and parallel to the continental slope farther in the north (Fig. 4c). We interpret this as indications for continued strong down-slope transport of glaciogenic debris sourced from the AT (Fig. 5c), which is also supported by the occurrence of mass transport deposits in this unit (Fig. 7). Farther seaward the material was then picked up by a re-circulating bottom current and shaped into leveedrifts (Figs. 2c and e and 5c).

The second depocentre lies between PITW and DGT. Its shape points towards material input along a broader front and not only via the shelf troughs (Fig. 4c). Supply of glaciogenic debris through PITW may have played a more important role than that through PITE during glacial intervals in this period (Fig. 5c). Patch drifts observed on the continental slope indicate a re-shaping of the material by bottom currents (Figs. 2 b and d, 6 b, and $6 \mathrm{c}$ ). We also suggest that during 


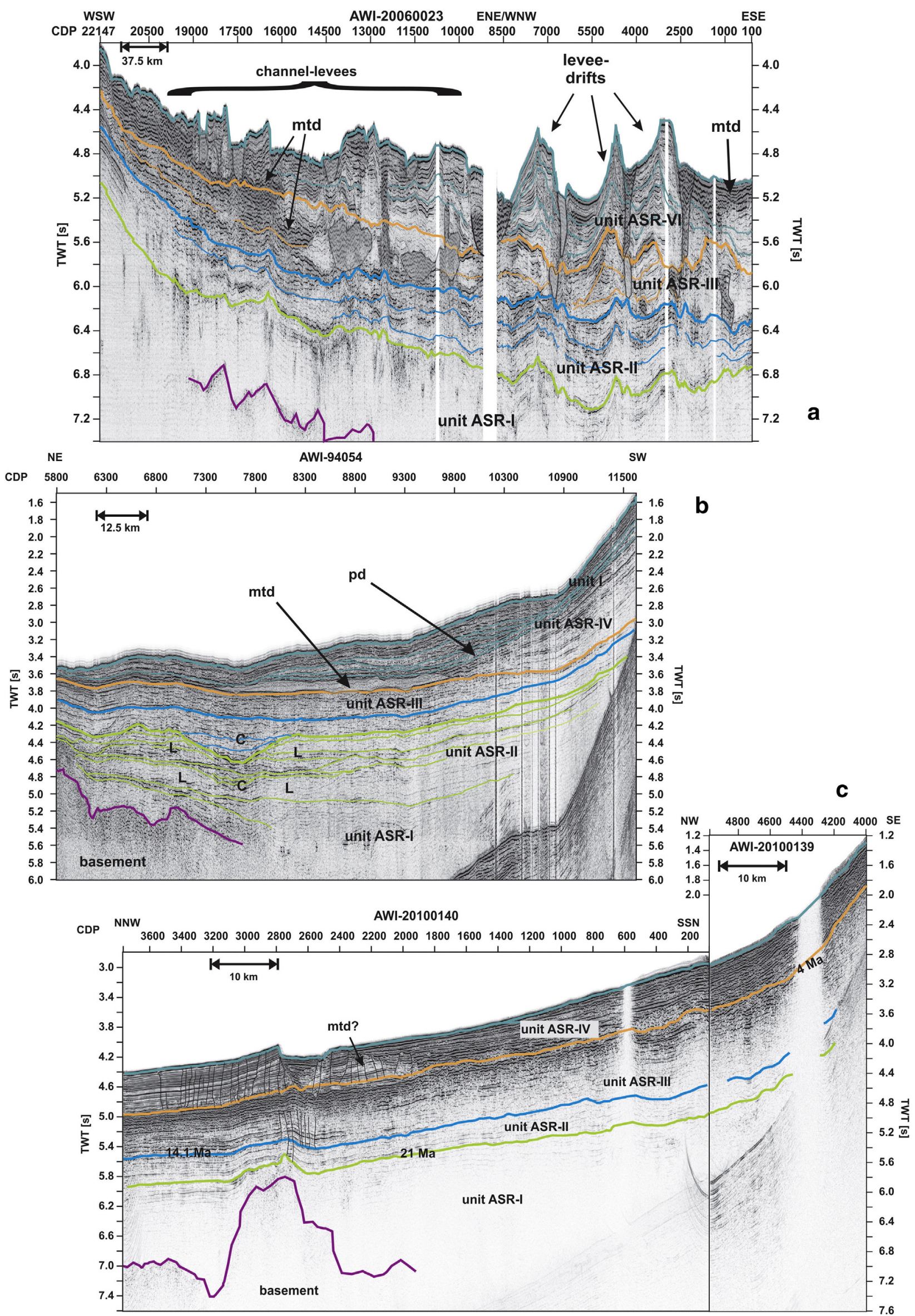



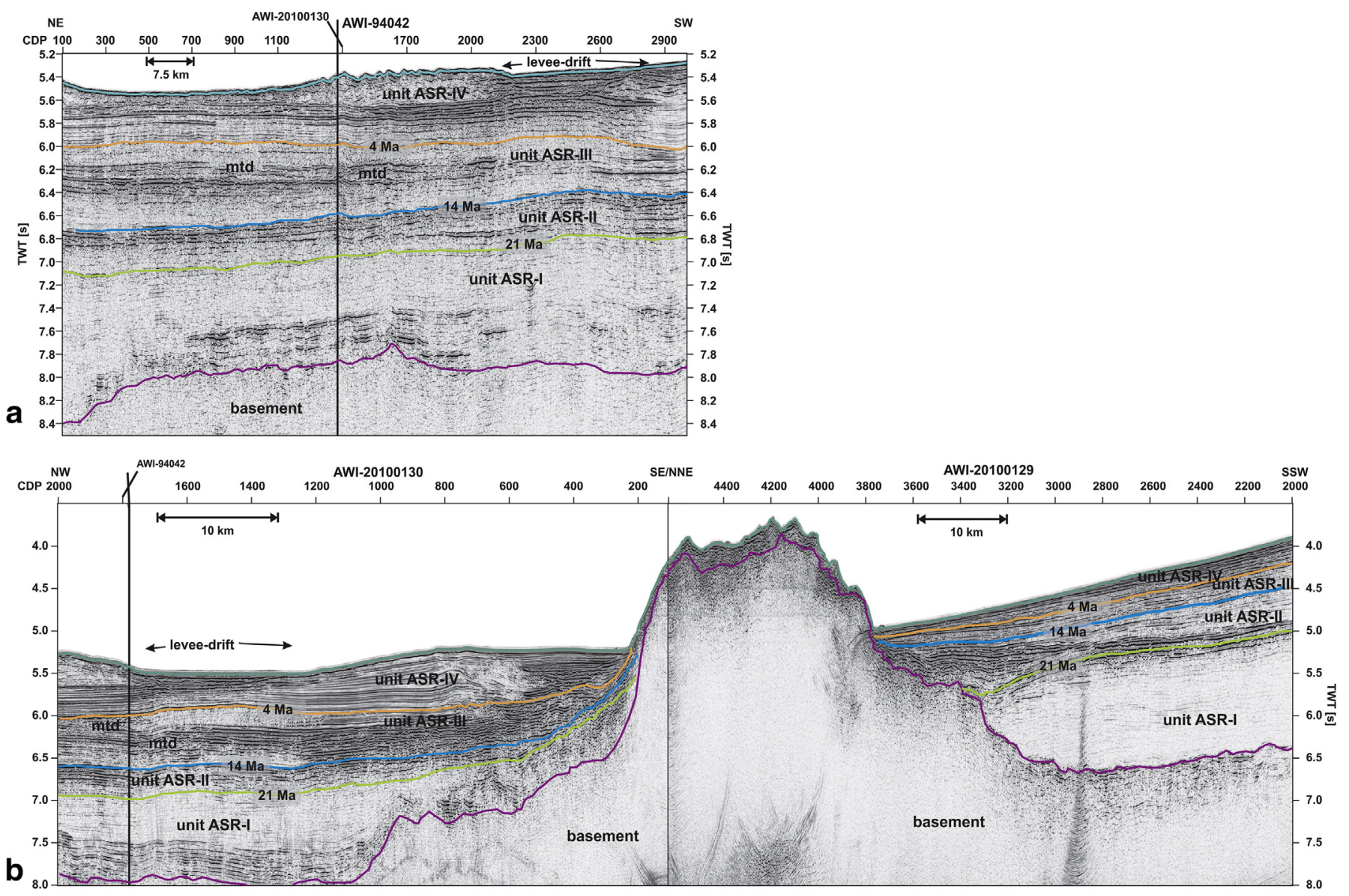

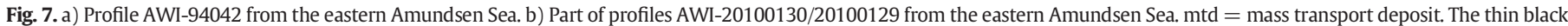
lines represent small-scale faults and the shaded areas filled channels. For location see Fig. 1.

intervals between 14 and 4 Ma ice streams advanced more frequently between PITW and DGT across the shelf and supplied the material to the depocentre observed on the adjacent slope and rise (Fig. 5c).

Less detrital input from the shelf may be a result of a cooler ice sheet following the major cooling event at the mid-Miocene Climate Transition (MMCT, 14 Ma, 1-2 my duration), which occurred at the Middle-Late Miocene boundary (Flower and Kennett, 1994). This reduced rates of glacial erosion and melt water production (Haywood et al., 2009). Gohl et al. (2013) infer a warm period for the latest Miocene/earliest Pliocene with a retreating ice sheet. According to them polythermal glacial activity resulted in high material input to the shelf, but appears to not have reached the continental slope.

For unit ASR-IV we observe three depocentres in the eastern Amundsen Sea, which are aligned perpendicular to the continental slope (Fig. 4d). The sedimentation rate has almost tripled compared to that of unit ASR-III, while the accumulation rate computed for the depocentres increased by a factor of 2.3 (Table 2). The size of the depocentres in unit ASR-IV is about the same as for unit ASR-III. Material input via AT and PITE appears to have been dominant.

Uenzelmann-Neben and Gohl (2012) report fewer mass transport deposits and sediment drifts that now are mainly observed in the central Amundsen Sea. They attributed this to less material input due to a change in ice-regime from wet- to dry based as proposed for other parts of the West Antarctic margin by Böhm et al. (2009) and Rebesco and Camerlenghi (2008), and consistent with WAIS advances across the Ross Sea shelf only during a few short glacial periods between
4 Ma and today (De Santis et al., 1999). Sedimentation rates and accumulation rates observed by us have strongly increased from unit ASR-III to unit ASR-IV (Table 2), which contradicts the formerly proposed reduced sediment input.

Unit thickness and sedimentation rates suggest a change from polythermal to dry-based ice already at 14.1 Ma with the onset of renewed cooling after the MMCT, which is consistent with the conclusion of Rocchi et al. (2006) for the glacial history of Marie Byrd Land. We propose that AT and PITE have been the primary outlets for the ice draining into the Amundsen Sea since $4 \mathrm{Ma}$ (Fig. 5d). Less material was provided via the DGT. This indicates that palaeo-ice streams emanating from today's Pine Island Glacier, Thwaites Glacier and Abbot Ice Shelf as well as Cosgrove Ice Shelf were quite dynamic and were frequently waxing and waning during glacial/interglacial stages of the past 4 Ma. Hochmuth and Gohl (2013) have observed a build-out of the outermost shelf of the AT by $75 \mathrm{~km}$ since the onset of glacial conditions. Gohl et al. (2013) suggested repeated advances of grounded ice to the outer shelf as the reason for progradation of the continental shelf since 3.7 Ma supporting our interpretation.

\section{Conclusions}

We analysed seismic reflection data from the continental slope and rise aiming at reconstructing sediment input (pathways and hence source areas on the shelf, amount) and sediment transport processes and to infer climatic and oceanographic changes. Thicknesses and

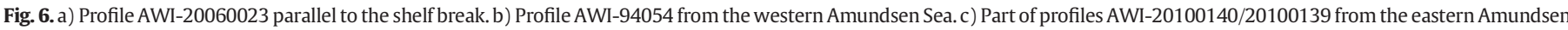

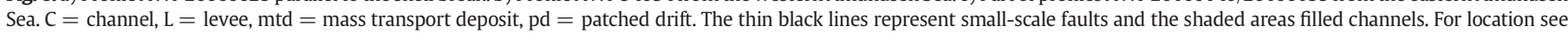
Fig. 1. 
depocentres of four sedimentary units were studied, which varied significantly through time, similar to the inferred sedimentation rates. The depocentres show distinct differences in location and shape. The oldest unit ASR-I ( $>21 \mathrm{Ma}$ ) shows a narrow depocentre parallel to the continental slope interpreted to represent low energy input (Fig. 5a). We have observed a focus in deposition near $106^{\circ} \mathrm{W}$ and attribute this to sediment supply through a palaeo-delta, which later became PITE. Sediment drifts observed in the elevated MBS area indicate an active water mass with a density between that of today's AABW and LCDW. This points towards a significant sea ice cover but not full glacial conditions for the period before $21 \mathrm{Ma}$.

For unit ASR-II (21-14.1 Ma) we observe a strong increase in sediment input documented by a larger depocentre and much higher sedimentation rates. We interpret this as evidence for glacial conditions in West Antarctica already during the Early Miocene. Warming as the result of the MMCO resulted in a wet-based ice sheet and led to a higher sediment supply. Glaciogenic debris was supplied from the shelf along a broad front but with a main pathway through PITE and AT (Fig. 5b). Most of the material was transported onto the eastern Amundsen Sea rise where it was shaped into levee-drifts by a re-circulating bottom current (Fig. 5b).

Unit ASR-III (14.1-4 Ma) is characterised by two smaller depocentres seaward of AT and PITW and reduced sedimentation rates (Fig. 5c). The onset of stronger cooling after $14 \mathrm{Ma}$ resulted in a cooler and dryer based ice sheet leading to less glacial erosion and less material input.

A dynamic ice sheet since 4 Ma characterised by growth and decay during cold and warm phases, respectively, is documented by a strong increase in sedimentation rates. Material was dominantly supplied to the rise via AT and PITW and much less sediment was provided from the western Amundsen Sea shelf (Fig. 5d). The pulsed glaciogenic debris input from the shelf interacted with a west-setting bottom current on the rise resulting in the continued formation of levee-drifts in the eastern and central Amundsen Sea (Fig. 5d).

The presented model is still tentative and suffers from the lack of age-depth and lithological information. Drill sites in the Amundsen Sea are desperately needed to gain high resolution insights into the evolution of climate and oceanography of West Antarctica. This study presents a basis for the identification of suitable drill locations.

\section{Acknowledgements}

We are grateful to the captains, crews and scientists for their support during the RV Polarstern cruises ANT-XI/3 (1994), ANT-XXIII/4 (2006) and ANT-XXVI-3 (2010) during which the data used in this paper were collected. Thanks go to C.-D. Hillenbrand, whose comments much improved this manuscript. We are further grateful for the helpful comments of two anonymous reviewers and the editor $\mathrm{H}$. Oberhänsli.

\section{References}

Anderson, J.B., 1999. Antarctic Marine Geology. Cambridge University Press, Cambridge. Anderson, J.B., et al., 2011. Progressive Cenozoic cooling and the demise of Antarctica's last refugium. PNAS 108, 11356-11360.

Arneborg, L., Wahlin, A.K., Bjork, G., Liljebladh, B., Orsi, A.H., 2012. Persistent inflow of warm water onto the central Amundsen shelf. Nat. Geosci. 5 (12), 876-880.

Assmann, K.M., et al., 2013. Variability of circumpolar deep water transport onto the Amundsen Sea Continental shelf through a shelf break trough. J. Geophys. Res. Oceans 118 (12), 6603-6620.

Bamber, J.L., Riva, R.E.M., Vermeersen, B.L.A., LeBrocq, A.M., 2009. Reassessment of the potential sea-level rise from a collapse of the West Antarctic Ice Sheet. Science 324 (5929), 901-903.

Bart, P.J., 2003. Were West Antarctic Ice Sheet grounding events in the Ross Sea a consequence of East Antarctic Ice Sheet expansion during the middle Miocene? Earth Planet. Sci. Lett. 216 (1-2), 93-107.

Bart, P.J., Sjunneskog, C., Chow, J.M., 2011. Piston-core based biostratigraphic constraints on Pleistocene oscillations of the West Antarctic Ice Sheet in western Ross Sea between North Basin and AND-1B drill site. Mar. Geol. 289 (1-4), 86-99.

Bentley, M.J., et al., 2010. Deglacial history of the West Antarctic Ice Sheet in the Weddell Sea embayment: constraints on past ice volume change. Geology 38 (5), 411-414.
Bijl, P.K., et al., 2013. Eocene cooling linked to early flow across the Tasmanian Gateway. Proc. Natl. Acad. Sci. 110 (24), 9645-9650.

Böhm, G., Ocakoglu, N., Picotti, S., De Santis, L., 2009. West Antarctic Ice Sheet evolution: new insights from a seismic tomographic 3D depth model in the Eastern Ross Sea (Antarctica). Mar. Geol. 266 (1-4), 109-128.

Bradley, S.L., Siddall, M., Milne, G.A., Masson-Delmotte, V., Wolff, E., 2012. Where might we find evidence of a Last Interglacial West Antarctic Ice Sheet collapse in Antarctic ice core records? Glob. Planet. Chang. 88â€“89 (0), 64-75.

Cooper, A.K., et al., 2009. Cenozoic climate history from seismic reflection and drilling studies on the Antarctic Continental Margin. In: Florindo, F., Siegert, M. (Eds.), Antarctic Climate Evolution. Developments in Earth and Environmental Sciences. Elsevier, pp. 115-228.

De Santis, L., Anderson, J.B., Brancolini, G., Zayatz, I., 1995. Seismic record of late Oligocene through Miocene glaciation on the central and eastern continental shelf of the Ross Sea. In: Cooper, A.F., Barker, P.F., Brancolini, G. (Eds.), Geology and Seismic Stratigraphy of the Antarctic Margin. American Geophysical Union, Washington, pp. 235-260.

De Santis, L., Prato, S., Brancolini, G., Lovo, M., Torelli, L., 1999. The Eastern Ross Sea continental shelf during the Cenozoic: implications for the West Antarctic Ice Sheet development. Glob. Planet. Chang. 23 (1-4), 173-196.

DeConto, R.M., Pollard, D., Kowalewski, D., 2012. Modeling Antarctic Ice Sheet and climate variations during Marine Isotope Stage 31. Glob. Planet. Chang. 88â€"89 (0), 45-52.

Domack, E.W., Jacobson, E.A., Shipp, S., Anderson, J.B., 1999. Late Pleistocene/Holocene retreat of the West Antarctic Ice-Sheet system in the Ross Sea: part 2 - sedimentologic and stratigraphic signature. Geol. Soc. Am. Bull. 111 (10), 1517-1536.

Dowdeswell, J.A., Evans, J., O Cofaigh, C., Anderson, J.B., 2006. Morphology and sedimentary processes on the continental slope off Pine Island Bay, Amundsen Sea, West Antarctica. Geol. Soc. Am. Bull. 118, 606-619.

Eagles, G., Gohl, K., Larter, R.D., 2004. High-resolution animated tectonic reconstruction of the South Pacific and West Antarctic Margin. Geochem. Geophys. Geosyst. 5.

Escutia, C., et al., 2009. Circum-Antarctic warming events between 4 and 3.5 Ma recorded in marine sediments from the Prydz Bay (ODP Leg 188) and the Antarctic Peninsula (ODP Leg 178) margins. Glob. Planet. Chang. 69 (3), 170-184.

Evans, J., Dowdeswell, J.A., O Cofaigh, C., Benham, T.J., Anderson, J.B., 2006. Extent and dynamics of the West Antarctic Ice Sheet on the outer continental shelf of Pine Island Bay during the last glaciation. Mar. Geol. 230, 53-72.

Expedition 318 Scientists, 2011. Expedition 318 summary. In: Escutia, C., Brinkhuis, H., Klaus, A., Expedition 318 Scientists (Eds.), Proceedings of the Integrated Ocean Drilling Program. IODP.

Flower, B.P., Kennett, J.P., 1994. The middle Miocene climatic transition: East Antarctic Ice Sheet development, deep ocean circulation and global carbon cycling. Palaeogeogr. Palaeoclimatol. Palaeoecol. 108 (3-4), 537-555.

Francis, J.E., et al., 2009. From greenhouse to icehouse - the Eocene/Oligocene in Antarctica. In: Florindo, F., Siegert, M. (Eds.), Antarctic Climate Evolution. Developments in Earth and Environmental Sciences. Elsevier, pp. 309-368.

Gohl, K., et al., 1997. Tectonic and sedimentary architecture of the Bellingshausen and Amundsen Sea Basins, SE Pacific, by seismic profiling. In: Ricci, C.A. (Ed.), The Antarctic Region: Geological Evolution and Processes. Terra Antartica Publication, Siena, pp. 719-723.

Gohl, K., et al., 2007. Geophysical survey reveals tectonic structures in the Amundsen Sea embayment, West Antarctica. In: Cooper, A.K., Raymond, C.R., al, e. (Eds.), Antarctica: A Keystone in a Changing World. USGS Open-File Report 2007-1047, Sta Barbara, USA.

Gohl, K., et al., 2013. Seismic stratigraphic record of the Amundsen Sea Embayment shelf from pre-glacial to recent times: evidence for a dynamic West Antarctic Ice Sheet. Mar. Geol. 344, 115-131.

Gomez, N., Mitrovica, J.X., Tamisiea, M.E., Clark, P.U., 2010. A new projection of sea level change in response to collapse of marine sectors of the Antarctic Ice Sheet. Geophys. J. Int. 180 (2), 623-634.

Gordon, A.L., et al., 2009. Western Ross Sea continental slope gravity currents. Deep-Sea Res. II Top. Stud. Oceanogr. 56 (13-14), 796-817.

Graham, A.G.C., et al., 2009. Bedform signature of a West Antarctic palaeo-ice stream reveals a multi-temporal record of flow and substrate control. Quat. Sci. Rev. 28 (25-26), 2774-2793.

Graham, A.G.C., et al., 2010. Flow and retreat of the Late Quaternary Pine Island-Thwaites palaeo-ice stream, West Antarctica. J. Geophys. Res. Earth Surf. 115, 12.

Haywood, A.M., et al., 2009. Middle Miocene to Pliocene History of Antarctica and the Southern Ocean. In: Florindo, F. Siegert M. (Eds.), Antarctic Climate Evolution. Developments in Earth and Environmental Sciences. Elsevier, pp. 401-463.

Hernandez-Molina, F.J., Larter, R.D., Rebesco, M., Maldonado, A., 2004. Miocene changes in bottom current regime recorded in continental rise sediments on the Pacific margin of the Antarctic Peninsula. Geophys. Res. Lett. 31.

Hillenbrand, C.-D., Ehrmann, W., 2005. Late Neogene to Quaternary environmental changes in the Antarctic Peninsula region: evidence from drift sediments. Glob. Planet. Chang. 45, 165-191.

Hillenbrand, C.-D., et al., 2008. The present and past bottom-current flow regime around the sediment drifts on the continental rise west of the Antarctic Peninsula. Mar. Geol. 255.

Hillenbrand, C.-D., et al., 2013. Grounding-line retreat of the West Antarctic Ice Sheet from inner Pine Island Bay. Geology 41 (1), 35-38.

Hochmuth, K., Gohl, K., 2013. Glaciomarine sedimentation dynamics of the Abbot glacial trough of the Amundsen Sea Embayment shelf, West Antarctica. Geol. Soc. Lond., Spec. Publ. 381 (1), 233-244.

Hu, A., Meehl, G.A., Han, W., Yin, J., 2011. Effect of the potential melting of the Greenland Ice Sheet on the Meridional Overturning Circulation and global climate in the future. Deep-Sea Res. II Top. Stud. Oceanogr. 58 (17-18), 1914-1926.

Huber, M., et al., 2004. Eocene circulation of the Southern Ocean: was Antarctica kept warm by subtropical waters? Paleoceanography 19. 
Ivany, L.C., Van Simaeys, S., Domack, E.W., Samson, S.D., 2006. Evidence for an earliest Oligocene ice sheet on the Antarctic Peninsula. Geology 34 (5), 377-380.

Iwai, M., Acton, G., Lazarus, D., Osterman, L.E., Williams, T., 2002. Magnetobiochronologic synthesis of ODP Leg 178 rise sediments from the Pacific Sector of the Southern Ocean: Sites 1095, 1096, and 1101. In: Barker, P.F., Camerlenghi, A., Acton, G.D., Ramsay, A.T.S. (Eds.), Proceedings of the Ocean Drilling Program, Scientific Results, volume 178. Ocean Drilling Program, College Station.

Jacobs, S.S., Hellmer, H.H., Jenkins, A., 1996. Antarctic Ice Sheet melting in the southeast Pacific. Geophys. Res. Lett. 23 (9), 957-960.

Jacobs, S.S., Jenkins, A., Giulivi, C.F., Dutrieux, P., 2011. Stronger ocean circulation and increased melting under Pine Island Glacier ice shelf. Nat. Geosci. 4 (8), 519-523.

Jacobs, S., et al., 2013. Getz Ice Shelf melting response to changes in ocean forcing. J. Geophys. Res. Oceans 118 (9), 4152-4168.

Jakobsson, M., Anderson, J.B., OSO0910, 2010. Multibeam mapping reveal past collapse of the Pine Island Bay ice shelf, West Antarctica. GEBCO 5th Science Day, Lima, Peru.

Jakobsson, M., et al., 2012. Ice sheet retreat dynamics inferred from glacial morphology of the central Pine Island Bay Trough, West Antarctica. Quat. Sci. Rev. 38, 1-10.

Kipf, A., et al., 2013. Seamounts off the West Antarctic margin: A case for non-hotspot driven intraplate volcanism. Gondwana Research 25, 1660-1667.

Kirshner, A.E., et al., 2012. Post-LGM deglaciation in Pine Island Bay, West Antarctica. Quat. Sci. Rev. 38, 11-26.

Klages, J.P., et al., 2013. First geomorphological record and glacial history of an inter-ice stream ridge on the West Antarctic continental shelf. Quat. Sci. Rev. 61, 47-61.

Konfirst, M.A., Scherer, R.P., Hillenbrand, C.-D., Kuhn, G., 2012. A marine diatom record from the Amundsen Sea: insights into oceanographic and climatic response to the Mid-Pleistocene Transition in the West Antarctic sector of the Southern Ocean. Mar. Micropaleontol. 92/93 (0), 40-51.

LeMasurier, W.E., 2008. Neogene extension and basin deepening in the West Antarctic rift inferred from comparisons with the East African rift and other analogues. Geology 36, 247-250.

Livingstone, S.J., et al., 2012. Antarctic palaeo-ice streams. Earth Sci. Rev. 111 (1/2), 90-128.

Lowe, A.J., Anderson, J.B., 2002. Reconstruction of the West Antarctic ice sheet in Pine Island Bay during the last glacial maximum and its subsequent retreat history. Quat. Sci. Rev. 21, 1879-1897.

Miller, K.G., Fairbanks, R.G., Mountain, G.S., 1987. Tertiary oxygen isotope synthesis, sea level history, and continental margin erosion. Paleoceanography 2 (1), 1-19.

Miller, K.G., Wright, J.D., Fairbanks, R.G., 1991. Unlocking the ice house: Oligocene-Miocene oxygen isotopes, eustasy, and margin erosion. J. Geophys. Res. 96, 6829-6848.

Miller, K.G., et al., 2008. A view of Antarctic ice sheet evolution from sea-level and deep-sea isotope changes during the Late Cretaceous-Cenozoic. In: Cooper, A.F., et al. (Eds.), Antarctica: A keystone in a changing world. National Academic Press, Washington, D.C., pp. $55-70$.

Naish, T., et al., 2007. A record of Antarctic climate and ice sheet history recovered. Eos 88 (50), 557-558

Naish, T., et al., 2009b. Chapter 11 Late Pliocene-Pleistocene Antarctic climate variability at orbital and suborbital scale: ice sheet, ocean and atmospheric interactions. Developments in Earth and Environmental SciencesElsevier, pp. 465-529.

Naish, T., et al., 2009a. Obliquity-paced Pliocene West Antarctic ice sheet oscillations. Nature 458 (7236), 322-328.

Nitsche, F.O., Gohl, K., Vanneste, K., Miller, H., 1997. Seismic expression of glacially deposited sequences in the Bellingshausen and Amundsen Sea, West Antarctica. In: Barker, P.F., Cooper, A.F. (Eds.), Geology and Seismic Stratigraphy of the Antarctic Margin, 2. American Geophysical Union, Washington, pp. 95-108.

Nitsche, F.O., Cunningham, A.P., Larter, R.D., Gohl, K., 2000. Geometry and development of glacial continental margin depositional systems in the Bellingshausen Sea. Mar. Geol. $162(2-4), 277-302$.

Nitsche, F.O., Jacobs, S.S., Larter, R.D., Gohl, K., 2007. Bathymetry of the Amundsen Sea continental shelf: implications for geology, oceanography, and glaciology. Geochem. Geophys. Geosyst. 8.

ÓCofaigh, C., et al., 2005. Flow of the West Antarctic Ice Sheet on the continental margin of the Bellingshausen Sea at the last glacial maximum. J. Geophys. Res. 110.

Orsi, A.H., 2010. Oceanography: recycling bottom waters. Nat. Geosci. 3 (5), 307-309.

Orsi, A.H., Wiederwohl, C.L., 2009. A recount of Ross Sea waters. Deep-Sea Res. II Top. Stud. Oceanogr. 56 (13-14), 778-795.

Orsi, A.H., Johnson, G.C., Bullister, J.L., 1999. Circulation, mixing, and production of Antarctic Bottom Water. Prog. Oceanogr. 43, 55-109.

Pollard, D., DeConto, R.M., 2009. Modelling West Antarctic ice sheet growth and collapse through the past five million years. Nature 458 (7236), 329-332.

Pritchard, H.D., et al., 2012. Antarctic ice-sheet loss driven by basal melting of ice shelves. Nature 484 (7395), 502-505.

Pross, J., et al., 2012. Persistent near-tropical warmth on the Antarctic continent during the early Eocene epoch. Nature 488.
Rebesco, M., Camerlenghi, A., 2008. Late Pliocene margin development and mega-debris flow deposits on the Antarctic continental margins: evidence of the onset of the modern Antarctic ice-sheet? Palaeogeogr. Palaeoclimatol. Palaeoecol. 260, 149-167.

Rebesco, M., Larter, R.D., Camerlenghi, A., Barker, P.F., 1996. Giant sediment drifts on the continental rise west of the Antarctic Peninsula. Geo-Mar. Lett. 16 (2), 65-75.

Rebesco, M., et al., 2002. Sediment drifts and deep-sea channel systems, Antarctic Peninsula Pacific Margin. In: Stow, D.A.V., Pudsey, C.J., Howe, J.A., Faugeres, J.-C., Viana, A.R. (Eds.), Deep-water Contourite Systems: Modern Drifts and Ancient Series, Seismic and Sedimentary Characteristics. Geological Society London, pp. 353-372.

Rocchi, S., LeMasurier, W.E., Di Vincenzo, G., 2006. Oligocene to Holocene erosion and glacial history in Marie Byrd Land, West Antarctica, inferred from exhumation of the Dorrel Rock intrusive complex and from volcano morphologies. Geological Society of America Bulletin 118 (7-8), 991-1005.

Scheuer, C., Gohl, K., Larter, R.D., Rebesco, M., Udintsev, G., 2006a. Variability in Cenozoic sedimentation along the continental rise of the Bellingshausen Sea, West Antarctica. Mar. Geol. 227 (3-4), 279-298.

Scheuer, C., Gohl, K., Udintsev, G., 2006b. Bottom-current control on sedimentation in the western Bellingshausen Sea, West Antarctica. Geo-Mar. Lett. 26 (2), 90-101.

Shipboard Scientific Party, 1975a. Site 274. In: Hayes, D.E., Frakes, L.A. (Eds.), Deep Sea Drilling Project, Initial Reports. US Government, Washington, pp. 369-433.

Shipboard Scientific Party, 1975b. Sites 270, 271, 272. In: Hayes, D.E., Frakes, L.A. (Eds.) Deep Sea Drilling Project, Initial Reports. US Government, Washington, pp. 211-334.

Shipboard Scientific Party, 1976. Site 324. In: Hollister, C.D., Craddock, C. (Eds.), Initial Reports. Deep Sea Drilling Project, Washington, D.C. , pp. 127-156.

Smellie, J.L., Haywood, A.M., Hillenbrand, C.-D., Lunt, D.J., Valdes, P.J., 2009. Nature of the Antarctic Peninsula Ice Sheet during the Pliocene: geological evidence and modelling results compared. Earth Sci. Rev. 94 (1-4), 79-94.

Thoma, M., Jenkins, A., Holland, D.M., Jacobs, S., 2008. Modelling circumpolar deep water intrusions on the Amundsen Sea continental shelf, Antarctica. Geophys. Res. Lett. 35 (18) L18602.

Tucholke, B.E., Houtz, R.E., 1976. Sedimentary framework of the Bellinghausen Basin from seismic profiler data. In: Hollister, C.D., Craddock, C. (Eds.), Initial Reports. Deep Sea Drilling Project, Washington, D.C. , pp. 197-227.

Tucholke, B.E., Edgar, N.T., Boyce, R.E., 1976a. Physical properties of sediments and correlations with acoustic stratigraphy: Leg 35, Deep Sea Drilling Project. In: Hollister C.D., Craddock, C. (Eds.), Initial Reports. Deep Sea Drilling Project, Washington, D.C. , pp. 229-249.

Tucholke, B.E., Hollister, C.D., Weaver, F.M., Vennum, W.R., 1976b. Continental rise and abyssal plain sedimentation in the southeast Pacific Basin: Leg 35 Deep Sea Drilling Project. In: Hollister, C.D., Craddock, C. (Eds.), Initial Reports. Deep Sea Drilling Project, Washington, D.C. , pp. 359-400.

Uenzelmann-Neben, G., 2006. Depositional patterns at Drift 7, Antarctic Peninsula: alongslope versus down-slope sediment transport as indicators for oceanic currents and climatic conditions. Mar. Geol. 233, 49-62.

Uenzelmann-Neben, G., Gohl, K., 2012. Amundsen Sea sediment drifts: archives of modifications in oceanographic and climatic conditions. Mar. Geol. 299-302, 51-62.

Uenzelmann-Neben, G., Gohl, K., Larter, R.D., Schlüter, P., 2007. Differences in ice retreat across Pine Island Bay, West Antarctica, since the last glacial maximum: indications from multichannel seismic reflection data. In: Cooper, A.K., Raymond, C.R.e.a. (Eds.) Antarctica - A keystone in a changing world. USGS Open File Report.

Van Aken, H.M., 2007. The Oceanic Thermohaline circulation. Atmospheric and Oceanographic Sciences Library. , 39. Springer, New York.

Weigelt, E., Gohl, K., Uenzelmann-Neben, G., Larter, R.D., 2009. Late Cenozoic ice sheet cyclicity in the western Amundsen Sea Embayment - evidence from seismic records. Glob. Planet. Chang. 69 (3), 162-169.

Weigelt, E., Uenzelmann-Neben, G., Gohl, K., Larter, R.D., 2012. Did massive glacial dewatering modify sedimentary structures on the Amundsen Sea Embayment shelf, West Antarctica? Glob. Planet. Chang. 92-93, 8-16.

Wellner, J.S., Lowe, A.J., Shipp, S.S., Anderson, J.B., 2001. Distribution of glacial geomorphic features on the Antarctic continental shelf and correlation with substrate: implications for ice behavior. J. Glaciol. 47, 391-411.

Wilson, G.S., Pekar, S.F., Naish, T.R., Passchier, S., DeConto, R., 2009. Chapter 9 The Oligocene-Miocene Boundary - Antarctic Climate Response to Orbital Forcing. In: Florindo, F., Siegert, M. (Eds.), Developments in Earth and Environmental Sciences. Elsevier, pp. 369-400.

Wilson, D.S., et al., 2012. Antarctic topography at the Eocene-Oligocene boundary Palaeogeogr. Palaeoclimatol. Palaeoecol. 335-336, 24-34.

Yamaguchi, K., Tamura, Y., Mizukosho, I., Tsuru, I., 1988. Preliminary report of geophysical and geological surveys in the Amundsen Sea, West Antarctica. Proc. NIPR Symp. Antarct. Geosci. 2, 55-67.

Yilmaz, Ö., 2001. Seismic Data Analysis. Investigations in Geophysics, 10. Society of Exploration Geophysicists, Tulsa (2027 pp.).

Zachos, J.C., Pagani, M., Sloan, L., Thomas, E., Billups, K., 2001. Trends, rhythms, and aberrations in global climate 65 Ma to present. Science 292, 686-693. 